\title{
Paulina Legutko-Kobus ${ }^{1}$, Maciej J. Nowak ${ }^{2}$
}

\section{Niesprawność władz publicznych w świetle prawno-przestrzennych i partycypacyjnych narzędzi rewitalizacji}

\begin{abstract}
Streszczenie
W artykule zaprezentowano argumenty wskazujące na niesprawność władz publicznych w systemie polityki przestrzennej. Punktem wyjścia jest analiza wykorzystania narzędzi kształtujących tę politykę, wprowadzonych dzięki uchwaleniu w 2015 r. ustawy o rewitalizacji, m.in. narzędzi związanych ze sferą prawno-przestrzenną i partycypacją. Niesprawność przejawia się w braku umiejętności, woli i determinacji do kształtowania i ochrony ładu przestrzennego. W rewitalizacji zaś przejawia się m.in.: niewłaściwym lub niepełnym zdiagnozowaniem problemów stanowiących podstawę dla przeprowadzenia rewitalizacji, brakiem woli władz publicznych w zakresie adekwatnej reakcji na zdiagnozowane problemy, brakiem aktywnej współpracy z interesariuszami (wynikającym zarówno z niskiego poziomu kapitału społecznego, jak i podejścia urzędów). W konsekwencji tylko władze pełnią funkcję podmiotu realizującego gminny program rewitalizacji, a brakuje innych interesariuszy i aktywności publicznej. Uwzględniając powyższe założenia, bezpośrednim celem artykułu jest określenie, czy i w jakim zakresie narzędzia rewitalizacji mogą ograniczać niesprawność władz publicznych w systemie gospodarki przestrzennej (w odniesieniu do obszarów rewitalizacji). Poniższa analiza wskazuje, że w badanych przypadkach narzędzia rewitalizacji nie są więc wykorzystywane w pełnym zakresie (obejmującym wszystkie powiązane z nimi możliwości). Także narzędzia z zakresu partycypacji nie są w pełni wykorzystane (szczególnie te związane z funkcjonowaniem Komitetu Rewitalizacji).
\end{abstract}

Słowa kluczowe: niesprawność władz publicznych, polityka przestrzenna, partycypacja, gminny program rewitalizacji, specjalna strefa rewitalizacji

Kody klasyfikacji JEL: R50, K49

DOI: $10.33119 / \mathrm{KSzPP} / 2020.3 .7$

1 Szkoła Główna Handlowa w Warszawie, e-mail: paulina.legutko-kobus@sgh.waw.pl, https://orcid. org/0000-0003-0380-8913

2 Zachodniopomorski Uniwersytet Technologiczny w Szczecinie, e-mail: macnowak@zut.edu.pl, https://orcid.org/0000-0001-8149-8995 


\title{
Inefficiency of public authorities in the light of legal, spatial, and participatory urban regeneration tools
}

\begin{abstract}
Enactment of the Polish Act on Urban Regeneration has granted municipalities new opportunities of using spatial policy development tools, including ones related to the legal, spatial, and participatory domain. The inefficiency of public authorities in the spatial management system manifests itself in insufficient skills as well as the lack of will and determination to shape and protect spatial order. Speaking of urban regeneration, this inefficiency becomes evident, but not only, in the erroneous or incomplete diagnosis of issues that should trigger regeneration processes; the lack of prompt and thoughtful response to the diagnosed problems; the lack of active cooperation with stakeholders (attributable both to the low level of social capital and the attitude of bureaucrats). Ultimately, this inefficiency leads to the implementation of the municipal regeneration program only by public authorities and not by regeneration stakeholders. Based on these findings, the article seeks to determine whether and to what extent urban regeneration tools can reduce the inefficiency of public authorities in the spatial management system (in relation to areas subject to regeneration). The conducted analysis of case studies demonstrates that regeneration tools are not employed to their full potential (to unlock all the related benefits). Participation tools are not fully utilized, either (especially those linked to the operation of the Urban Regeneration Committee).
\end{abstract}

Keywords: inefficiency of public authorities, spatial policy, participation, municipal regeneration program, special regeneration zone

JEL Classification Codes: R50, K49

Polityka przestrzenna obejmuje zróżnicowane sfery zagadnień, jak i narzędzia programowania i implementacji. Adekwatnie do tego można wyodrębnić zarówno podstawowe narzędzia polityki przestrzennej (studium uwarunkowań i kierunków zagospodarowania przestrzennego, miejscowy plan zagospodarowania przestrzennego itd.), jak również narzędzia sektorowe związane z rewitalizacją (Nowak, 2017: 83-88). Mogą one być postrzegane samodzielnie lub holistycznie, jako element szerszego systemu - tak są postrzegane w niniejszym artykule - jako element systemu gospodarki przestrzennej. Ich stosowanie ma bowiem prowadzić również do optymalnego zagospodarowania terenu powiązanego $\mathrm{z}$ gwarancją zaprogramowania implementacji i ochrony ładu przestrzennego. Po tym zastrzeżeniu należy wskazać, że narzędzia polityki przestrzennej powiązane z procesem rewitalizacji w niniejszym artykule będą określane jako narzędzia rewitalizacji (przy świadomości możliwych 
wątpliwości odnośnie do faktycznego miejsca rewitalizacji w systemie gospodarki przestrzennej). Można je sklasyfikować następująco:

- narzędzia związane ze sferą prawno-przestrzenną (uchwała wyznaczająca obszar rewitalizacji, gminny program rewitalizacji, miejscowy plan rewitalizacji, uchwała wyznaczająca specjalną strefę rewitalizacji),

- narzędzia partycypacji (szczególnie w kontekście podejmowanej tematyki: konsultacje społeczne i Komitet Rewitalizacji).

$\mathrm{W}$ artykule skupiono się na narzędziach ujętych w ustawie z dnia 9 października 2015 r. o rewitalizacji, w powiązaniu z systemem gospodarki przestrzennej. Niniejsza ustawa stanowi zresztą $\mathrm{w}$ teoretycznym ujęciu modelowy przykład opisanego przez A. Zybałę (2012: 48-49) działania organów władz publicznych w związku ze zdiagnozowaniem problemów w sferze publicznej. Narzędzia prawno-przestrzenne wywierają bezpośredni wpływ na zagospodarowanie przestrzeni, a także na inne narzędzia polityki przestrzennej (stanowiąc czasem ich zmodyfikowane formy). Przykładowo, może występować współzależność gminnego programu rewitalizacji (zawierającego koncepcję zwłaszcza przedsięwzięć rewitalizacyjnych) z treścią obowiązujących studiów uwarunkowań i kierunków zagospodarowania przestrzennego oraz miejscowych planów zagospodarowania przestrzennego.

Narzędzia partycypacji mają za zadanie umożliwić interesariuszom ${ }^{3}$ udział $\mathrm{w}$ podejmowaniu decyzji w zakresie rewitalizacji oraz udział we wdrażaniu projektów rewitalizacyjnych. Partycypacja docelowo ma również podwyższać kapitał społeczny interesariuszy, a w konsekwencji prowadzić do skuteczniejszych i bardziej uspołecznionych reguł gospodarowania przestrzenią.

Wskazane narzędzia zostały wprowadzone (w obecnej formie) w 2015 r., z wyraźną intencją korekty przynajmniej części elementów diagnozowanej niesprawności władz publicznych w systemie gospodarki przestrzennej. W ramach analiz w niniejszym artykule nie uwzględniono innych wyodrębnianych narzędzi rewitalizacji (np. finansowych), w przypadku których bezpośredni związek z systemem gospodarki przestrzennej jest słabszy.

3 Zgodnie z zapisami ustawy o rewitalizacji (art. 2 ust. 2.) interesariuszami rewitalizacji są w szczególności: 1) mieszkańcy obszaru rewitalizacji oraz właściciele, użytkownicy wieczyści nieruchomości i podmioty zarządzające nieruchomościami znajdującymi się na tym obszarze, w tym spółdzielnie mieszkaniowe, wspólnoty mieszkaniowe i towarzystwa budownictwa społecznego, 2) inni (niż wymienieni w pkt. 1 mieszkańcy gminy, 3) podmioty prowadzące lub zamierzające prowadzić na obszarze gminy działalność gospodarczą, 4) podmioty prowadzące lub zamierzające prowadzić na obszarze gminy działalność społeczną, w tym organizacje pozarządowe i grupy nieformalne, 5) jednostki samorządu terytorialnego i ich jednostki organizacyjne, 6) organy władzy publicznej, 7) podmioty realizujące na obszarze rewitalizacji uprawnienia Skarbu Państwa. 
Celem artykułu jest określenie, czy i w jakim zakresie wprowadzone przez ustawę narzędzia rewitalizacji mogą ograniczać niesprawność władz publicznych w polityce przestrzennej (w odniesieniu do obszarów rewitalizacji). Tak sformułowany cel zdeterminował układ artykułu i zastosowane metody badawcze. W strukturze tekstu wyróżnić można dwie zasadnicze części - teoretyczną, opartą na krytycznej analizie literatury przedmiotu z zakresu niesprawności władz publicznych i prawno-przestrzennych narzędzi rewitalizacji oraz dotyczącą ujęcia partycypacji w procesach rewitalizacji. Część druga tekstu stanowi analizę konkretnych zapisów dokumentów planistycznych i rozwiązań przyjętych $w$ ramach partycypacji, $w$ wybranych gminach. Badaniami objęto pięć gmin, zróżnicowanych zarówno pod względem administracyjnym, jak i przyjętych kierunków rozwoju. Taki układ artykułu pozwolił na sformułowanie w podsumowaniu konstatacji ogólnych i szczegółowych, związanych ze specyfiką analizowanych gmin.

\section{Niesprawność władz publicznych i kierunki jej ograniczania}

W literaturze przedmiotu wielokrotnie przeprowadzano analizy zagadnienia niesprawności władz publicznych w systemie gospodarki przestrzennej. Zdaniem Zybały (2019: 112), państwo nie wypracowało narzędzi programowania i implementowania polityki przestrzennej, nie posiadając tym samym wystarczającego wpływu na sterowność procesów przestrzennych. Obejmuje to zarówno sferę programowania, implementowania, jak i ewaluacji. Jest to odzwierciedlane:

- nieumiejętnością/niemożnością w obecnych realiach usuwania ułomności mechanizmów rynkowych (Markowski, 2010: 28; Feltynowski, 2018: 90-95; Drzazga, 2018: 47-54; Kowalewski, 2019: 265-267; Mikuła, 2019: 22-31).

- słabościami natury instytucjonalnej (problemy z określaniem zakresu kompetencji organów, nadmierna rola przepisów o charakterze proceduralnym, skłonność do biurokratyzacji - Nowak, 2007: 118).

Nadrzędnym celem całego systemu gospodarki przestrzennej jest uzyskanie ładu przestrzennego. To ogólne założenie znajduje różne ucieleśnienie na różnych terenach. Dążenie do ładu przestrzennego musi być skoordynowane z realizacją programów rewitalizacji obszarów zdegradowanych (eliminacja i ograniczanie problemów występujących na tych obszarach). Oznaczać to będzie szczegółową weryfikację zróżnicowanych wskaźników (których najszersze ujęcie zaprezentował Śleszyński, 2013: 178-229).

W tym kontekście istotnym punktem odniesienia jest rozumienie przestrzeni jako dobra publicznego. Jej kluczowa cecha - niewykluczalność (z prawa do wspólnej 
przestrzeni nie można wykluczać wybranych podmiotów) - na ogół jest dobrze powiązana z celami programów rewitalizacyjnych, które obejmują ograniczanie i eliminowanie problemów społecznych, przestrzennych, środowiskowych itd. Natomiast trochę inaczej należy postrzegać postulat nierywalizacyjnego charakteru przestrzeni (kolejna cecha dobra publicznego, a przynajmniej jego części). W literaturze (Nowak, 2017: 49) do dóbr publicznych zaliczono walory środowiskowe, przyrodnicze, kompozycyjno-estetyczne i funkcjonalne danej przestrzeni. Również te dobra są kształtowane i chronione (odtwarzane) w ramach procesu rewitalizacji. Warto tu przywołać uwagi Ostrom (2012: 95) dotyczące weryfikacji regulacji umożliwiających dostęp do dóbr publicznych (a przepisy dotyczące rewitalizacji, jak wskazano powyżej, pełnią również taką funkcję).

Generalnie niesprawność władz publicznych w polityce przestrzennej polega na braku ich szeroko rozumianych umiejętności, woli działania i determinacji w kształtowaniu i ochronie ładu przestrzennego. Z kolei w sferze rewitalizacji ich niesprawność - zachowując to samo ujęcie - sprowadza się do zagrożenia wystąpienia następujących tendencji:

- niewłaściwego lub niepełnego diagnozowania problemów, które zwykle wymagają podjęcia rewitalizacji, w tym niewłaściwego wyodrębnienia dóbr publicznych podlegających ochronie,

- braku woli władz publicznych w zakresie adekwatnej reakcji na zdiagnozowane problemy,

- braku możliwości adekwatnej reakcji na zdiagnozowane problemy,

- przeciwskutecznej reakcji na zdiagnozowane problemy,

- powikłań biurokratyczno-instytucjonalnych związanych z działaniami władz publicznych,

- braku mapowania interesariuszy i posługiwania się jedynie enumeratywną ich listą wynikającą z zapisów ustawy,

- niepełnego zaangażowania interesariuszy w procesy rewitalizacji wynikającego z niskiego poziomu kapitału społecznego,

- realizowania gminnego programu rewitalizacji jedynie przez władze, a nie interesariuszy rewitalizacji.

\section{Prawno-przestrzenne narzędzia rewitalizacji}

Staszewska i Dajek (2018: 25-27, 31) zwracają uwagę na relacje zarządzania przestrzennego i strategicznego w kontekście procesu rewitalizacji. Zarządzanie przestrzenne w takim ujęciu powinno uwzględniać trzy formy użytkowania przestrzeni: 
- aktualną,

- potencjalną,

- postulowaną.

Zarządzanie przestrzenne służy wypracowaniu drogi do uzyskania ładu przestrzennego, a zarządzanie strategiczne ma na celu wielodziedzinowy sukces w gminie. Określenie drogi do uzyskania ładu urbanistyczno-architektonicznego, funkcjonalnego, estetycznego, społecznego i ekologiczno-środowiskowego, uwzględniającego potrzeby i kierunki rozwoju danej jednostki samorządu terytorialnego, musi więc być przeprowadzane z uwzględnieniem obu obszarów zarządzania.

Do takiego ujęcia można dodać zastrzeżenie, że w ramach rewitalizacji niniejsza formuła musi być wyraźnie ograniczona zarówno terytorialnie, jak też przedmiotowo. W ramach konkretnej rewitalizacji przedsięwzięcia mieszczące się w powyższych wytycznych muszą być szczegółowo zawężone (w innym przypadku narzędzia rewitalizacji utracą swój specyficzny charakter). W literaturze wskazuje się zresztą na dominujące problemy w obszarach rewitalizacji (por. np. Litwińska, 2011:32-34). Za trafną należy w tym kontekście uznać konkluzję Lorensa $(2016: 16-17,20)$ podkreślającego rolę planowania zintegrowanego w procesie rewitalizacji i wyodrębniającego trzy grupy celów rewitalizacji: społeczne, przestrzenne oraz gospodarcze. Cele te są oczywiście ze sobą wzajemnie powiązane.

Związane z realizacją tych celów prawno-przestrzenne narzędzia rewitalizacji to:

- uchwała wyznaczająca obszar rewitalizacji,

- gminny program rewitalizacji (dalej GPR),

- uchwała wyznaczająca specjalną strefę rewitalizacji,

- miejscowy plan rewitalizacji.

Narzędzia rewitalizacji (możliwe do powiązania z systemem gospodarki przestrzennej) na podstawie ustawy o rewitalizacji:

- uchwała rady gminy wyznaczająca obszar zdegradowany i obszar rewitalizacji - akt powszechnie wiążący, w ramach którego (fakultatywnie) można także ustanowić prawo pierwokupu na rzecz gminy wszystkich nieruchomości położonych w obszarze rewitalizacji, oraz zakaz lub ograniczenie w wydawaniu decyzji o warunkach zabudowy i zagospodarowania terenu

- gminny program rewitalizacji - kompleksowa koncepcja rewitalizacji przyjmowana $\mathrm{w}$ formie uchwały rady gminy (ale nie jako akt powszechnie wiążący), wyznaczająca m.in. przedsięwzięcia rewitalizacyjne; musi być zgodna z gminnymi aktami polityki przestrzennej 
- miejscowy plan rewitalizacji - szczególna forma miejscowego planu zagospodarowania przestrzennego, fakultatywny akt powszechnie wiążący, dający organom gminy możliwość szerszej niż zwykły plan miejscowy ingerencji w przestrzeń (np. nakazu zakończenia określonej działalności na danym obszarze)

- uchwała rady gminy wyznaczająca specjalną strefę rewitalizacji - akt powszechnie wiążący, uchwalany fakultatywnie po uchwaleniu gminnego programu rewitalizacji, stanowiący podstawę do udzielania przez gminę dotacji względem określonych robót budowlanych (prowadzonych w strefie) oraz umożliwiający wprowadzenie zakazu/ograniczeń względem wydawania decyzji o warunkach zabudowy i zagospodarowania terenu. Względem nieruchomości położonych w strefie przyporządkowano z mocy prawa prawo pierwokupu na rzecz gminy

W obecnej praktyce zdecydowanie szerszy zakres zastosowania mają dwa pierwsze narzędzia rewitalizacji, do nich więc w przeważającym zakresie odnosi się analiza. Uchwała wyznaczająca obszar rewitalizacji stanowi akt powszechnie wiążący (Nowak, Tokarzewska, 2016: 37; Szlachetko J., Szlachetko K., 2019: 33). Opiera się w znaczącym zakresie na przeprowadzonych wcześniej (obiektywnych i możliwych do zweryfikowania) diagnozach określających kluczowe problemy (społeczne, przestrzenne itd.) danego obszaru. Ustawodawca przy różnych rozwiązaniach związanych z systemem gospodarki przestrzennej podejmował próby szerszego powiązania konkretnych narzędzi z częścią diagnostyczną. W przeważającej części przypadków - co stanowi zresztą jeden z wyrazów niesprawności władz publicznych - próby te się nie udały.

Gminny program rewitalizacji - przewidziany w ustawie o rewitalizacji - zgodnie z koncepcją Staszewskiej i Dajek będzie raczej dokumentem strategicznym. Należy jednak nadmienić, że zgodnie z obowiązującymi przepisami nie może on obejmować więcej niż $20 \%$ powierzchni i 30\% mieszkańców gminy. Jest to więc narzędzie odnoszące się do fragmentu przestrzeni (w praktyce powstają programy rewitalizacji obejmujące nawet mniej niż $1 \%$ powierzchni gminy). Takie podejście sprawia, że narzędzie w teorii wydające się odgrywać kluczową rolę w ograniczaniu niesprawności władz publicznych, w praktyce obejmuje jedynie część gminy.

Kluczowy element GPR to określony katalog przedsięwzięć rewitalizacyjnych, opracowanych jako odpowiedź na zdiagnozowane wcześniej problemy (jednak, jak wyszukano, tylko dla niewielkiego odsetka powierzchni, tj. obszaru rewitalizacji). Kolejna ważna kwestia to wymóg spójności programu ze studium uwarunkowań i kierunków zagospodarowania przestrzennego i miejscowym planem zagospodarowania przestrzennego. Program nie stanowi jednak aktu powszechnie wiążącego 
i jego sfera realizacyjna ma być skojarzona ze Specjalną Strefą Rewitalizacji lub miejscowym planem rewitalizacji.

Ten ostatni jako szczególna forma miejscowego planu zagospodarowania przestrzennego stwarza możliwość (w przeważającym zakresie wciąż jedynie teoretyczną) szerszej ingerencji w przestrzeń, związaną również z formułowaniem podstaw do zawierania umów urbanistycznych. GPR w swojej formule teoretycznie mają sposobność pogłębienia również aspektu związanego z polityką przestrzenną w ramach obszaru rewitalizacji.

Specjalna Strefa Rewitalizacji umożliwia instytucjonalne ograniczenie szkodliwych z perspektywy polityki przestrzennej decyzji o warunkach zabudowy. Można więc zauważyć pewien potencjał w ograniczaniu niesprawności władz publicznych w systemie gospodarki przestrzennej.

\section{Partycypacja w procesie rewitalizacji}

Znaczenie partycypacji w procesach rozwoju, $w$ tym $w$ ich usprawnianiu i legitymizowaniu decyzji podejmowanych przez władze, podkreślane jest od końca lat 60 . XX w., kiedy to sformułowano tzw. drabinę partycypacji, w której następuje stopniowe przechodzenie od „pustych rytuałów” do realnego współrządzenia (Arnstein, 1969: 216). W procesach rewitalizacji szczególnie istotny jest ich społeczny kontekst, stanowiący kluczowy element wyprowadzania danego obszaru ze stanu kryzysowego. Wymiar społeczny rewitalizacji opiera się na założeniu, że społeczeństwo jest jednocześnie i podmiotem, i uczestnikiem procesu, a dzięki udziałowi i uczestnictwu może zabezpieczyć wspólne interesy (Muszyńska-Jeleszyńska, 2015: 259).

Współcześnie literatura i praktyka procesów partycypacji wskazują na rosnące znaczenie dywersyfikacji narzędzi partycypacji i coraz szersze wdrożenie e-partycypacji (Hejduk, 2018; Nowakowska, Legutko-Kobus, Walczak, 2019: 68-69). W literaturze zwraca się uwagę, że kluczowymi interesariuszami są już nie tylko władze lokalne, mieszkańcy i biznes, ale także organizacje pozarządowe, niezależni aktywiści (w tym także programiści) oraz media (szczególnie lokalne) (Kassen 2020: 16-17).

Ustawa o rewitalizacji (2015) cały rozdział 2 poświęca problemowi partycypacji, w tym podkreśla potrzebę aktywnego udziału interesariuszy w procesie przygotowania, prowadzenia i oceny rewitalizacji. Szczególną formą partycypacji wymienianą w ustawie są prace Komitetu Rewitalizacji, czyli organu opiniodawczo-doradczego wójta/burmistrza/prezydenta miasta. Do zadań Komitetu (zgodnie z zapisami ustawy) należy opiniowanie: projektu GPR (o ile Komitet został powołany przed uchwaleniem 
GPR), aktów planistycznych, projektu uchwały o ustanowieniu Specjalnej Strefy Rewitalizacji oraz oceny aktualności i stopnia realizacji GPR (art. 7).

Jak na warunki polskie, w których przeważa model konsultacyjno-opiniodawczy przygotowania dokumentów planistycznych i strategicznych (Olech, Kaźmierczak, 2011), wymagania stawiane konsultacjom gminnych programów rewitalizacji (i szerzej partycypacji w procesie rewitalizacji) należy uznać za sprzyjające wdrożeniu idei governance, ograniczeniu niesprawności władz publicznych oraz włączeniu wiedzy i doświadczenia interesariuszy (mogących stanowić dopełnienie kompetencji urzędników) w procesy rozwoju gminy. Ustawa wymienia także formy konsultacji społecznych, do których zaliczono:

- zbieranie uwag w postaci papierowej lub elektronicznej, w tym za pomocą środków komunikacji elektronicznej, w szczególności poczty elektronicznej lub formularzy zamieszczonych na stronie podmiotowej gminy w Biuletynie Informacji Publicznej,

- konsultacje w formie: spotkań, debat, warsztatów, spacerów studyjnych, ankiet, wywiadów z grupami przedstawicielskimi lub zbierania uwag ustnych.

Ustawa nie tylko enumeratywnie wymienia możliwe formy konsultacji, ale także nakłada na gminę obowiązek zastosowania co najmniej dwóch, innych niż zbieranie uwag, form konsultacji. Dla wielu gmin jest to wyzwanie merytoryczne i organizacyjne w porównaniu $\mathrm{z}$ dotychczas stosowanymi formami partycypacji w procesach rozwojowych. Jak wskazują badania (Hołuj, Legutko-Kobus, 2018a) zarówno zapisy ustawy, jak i praktyka ich stosowania zapewniają partycypację w procesach przygotowywania programów rewitalizacji, ale ich formy i narzędzia są raczej bierne, polegające na konsultacji, a nie współuczestnictwie. Wynika to z jednej strony z niesprawności władz i nieumiejętności prowadzenia procesów partycypacji (czasem braku przekonania do nich), jak i słabości kapitału społecznego, obecności „milczącej większości”, która nie chce się angażować w sprawy lokalne (Hołuj, Legutko-Kobus, 2018b). Partycypacja ma więc głównie wymiar sformalizowanego modelu współpracy, zarządzanego odgórnie (Donderowicz, Główczyński, Wronkowski, 2016: 43). Przywiązanie mieszkańców do zasad demokracji przedstawicielskiej może się objawiać wręcz oczekiwaniem rozwiązania problemów przez władze, a dodatkowo zazwyczaj niewielka aktywność społeczna na obszarach problemowych także nie sprzyja szerokiej partycypacji (Mielczarek-Żejmo, 2019: 107).

W literaturze zidentyfikowano bariery związane z partycypacją w procesie rewitalizacji, zaliczając do nich kilka kategorii (Badanie efektywności..., 2011: 7; Hołuj, Legutko-Kobus 2018b: 39-42; Leszkowicz-Baczyński, Marcinów 2019: 18-19, 29; Nowakowska, Legutko-Kobus, Walczak, 2019: 35-37, 50-52; Rembarz, 2016: 27-28): 
- kategoria pierwsza, tj. organizacyjno-zarządcza, ale rzutująca na prowadzenie procesu partycypacji i możliwość ograniczania niesprawności władz publicznych, tj. umiejscowienie komórki ds. rewitalizacji w urzędzie (np. powiązanie $\mathrm{z}$ funduszami europejskimi, planowaniem przestrzennym) i jej powiązania (a często ich brak) z komórką ds. partycypacji,

- druga wynikająca z błędów zarządzania relacjami z interesariuszami - gminy często nie mają pełnej wiedzy nt. interesariuszy procesów rewitalizacji (zamiast budować ich mapy obejmujące: analizy powiązań, siły odziaływania, kompetencje, preferowane formy komunikacji, poprzestają na liście interesariuszy wymienionej w ustawie). Ponadto współczesny aktywizm, szczególnie miejski, charakteryzuje znaczne zróżnicowanie pod względem: celów, zadań, poczucia sprawstwa, co może się przekładać na podejście do partycypacji jako „gry o przestrzeń” lub sposobu na doraźne rozwiązywanie problemów,

- prowadzi to do kolejnej, trzeciej grupy barier, tj. niedopasowania form i narzędzi partycypacji do dotychczasowych doświadczeń interesariuszy. Pojawiają się tu kolejne bariery wynikające z trudności w percepcji samego procesu, szczególnie delimitacji i wyznaczania obszaru zdegradowanego czy obszaru rewitalizacji. Nakładają się na to jeszcze ogólne bariery związane z partycypacją w procesach rozwojowych, tj. traktowanie jej tylko jako wymogu prawnego i przystąpienie do procesu partycypacji jako oczekiwania dla akceptacji gotowego rozwiązania przygotowanego ekspercko lub przez władze (Długosz, Wygnański, 2005; Badanie efektywności, 2011; Noworól A., Noworól K., Hałat, 2012: 27).

\section{Narzędzia rewitalizacji w badanych gminach}

Chcąc osiągnąć sformułowany w artykule cel, przeprowadzono badanie w formie studiów przypadku wybranych jednostek samorządu terytorialnego. Do analizy wybrano z puli samorządów gminy, które w marcu 2020 r. miały przyjęte uchwały o wyznaczeniu Specjalnej Strefy Rewitalizacji. Dążąc do próby uchwycenia, czy stosowane narzędzia mają specyficzny charakter, czy stosują je wszystkie gminy bez względu na charakter administracyjny i przyjęte strategiczne kierunki rozwoju, do analizy wybrano gminy: Gnojnik, Krynica-Zdrój, Łódź, Milanówek oraz Płock.

Gmina Gnojnik to gmina wiejska leżąca w województwie małopolskim, licząca 8027 mieszkańców ${ }^{4}$. GPR przyjęto w 2017 r. Powierzchnia obszaru rewitalizacji sta-

4 Liczba mieszkańców wszystkich analizowanych gmin podawana za: GUS, dane na 31 grudnia $2018 \mathrm{r}$. 
nowi 6,98\% powierzchni gminy (wskazano podobszary: I - Gnojnik, II - Uszew oraz III - Biesiadki) i zamieszkuje ją 20,8\% mieszkańców.

Krynica-Zdrój to gmina miejsko-wiejska, którą zamieszkuje 16777 mieszkańców. GPR opracowano w 2017 r., obejmuje powierzchnią tylko 1,44\% terenu gminy (wskazano podobszary I - Krynica-Zdrój Centrum oraz II-Muszynka). Jest to obszar gęsto zaludniony, gdyż zamieszkuje go 27,52\% wszystkich mieszkańców.

Łódź to stolica województwa, licząca 685285 mieszkańców. Obowiązująca wersja GPR została opracowana w 2018 r. (poprzednia wersja była z 2016 r.). Obszar rewitalizacji obejmuje 6,08\% powierzchni miasta, a zamieszkuje go 22,83\% ludności.

Milanówek to miasto-ogród w woj. mazowieckim, zamieszkałe przez 16306 mieszkańców. GPR uchwalono w 2017 r., powierzchnia obszaru rewitalizacji wynosi $17,43 \%$ powierzchni miasta (wyznaczono cztery podobszary: Centrum, ul. Gospodarska, ul. Okrzei, Turczynek). Obszar rewitalizacji zamieszkuje 27,5\% ludności miasta.

Płock, miasto w subregionie na Mazowszu, liczące 120000 mieszkańców. Powierzchnia obszaru rewitalizacji to: 7,96\%, zamieszkiwana przez 27,90\% ludności. GPR przyjęty w 2016 r., a następnie zmieniany w latach 2017 i 2019. Obejmuje cztery podobszary (I - Stare Miasto, Kolegialna, II-Dobrzyńska, Skarpa, III - Radziwie oraz IV - teren byłej Cukrowni Borowiczki).

Wskazane gminy przeanalizowano w kontekście stosowania następujących narzędzi rewitalizacji:

- powiązań gminnego programu rewitalizacji z dokumentami planowania przestrzennego, w tym z zapisami uchwał wyznaczających Specjalne Strefy Rewitalizacji,

- stosowanych narzędzi partycypacji w procesie wyznaczania obszaru rewitalizacji, uchwalania GPR (ewentualnie oceny i aktualizacji), konsultowania składu Komitetu Rewitalizacji i jego działania.

Wyniki przeprowadzonych badań przedstawiają tabele 1 i 2 .

Tabela 1. Narzędzia rewitalizacji w badanych gminach i ich możliwe przełożenie na politykę przestrzenną

\begin{tabular}{|c|c|c|}
\hline Gmina & $\begin{array}{l}\text { Charakterystyka wybranych postanowień gminnych programów } \\
\text { rewitalizacji ujmujących kontekst związany z polityką przestrzenną }\end{array}$ & $\begin{array}{l}\text { Ponadstandardowe postanowienia } \\
\text { uchwał wyznaczających obszar } \\
\text { rewitalizacji, postanowienie uchwał } \\
\text { wyznaczających Specjalne Strefy } \\
\text { Rewitalizacji }\end{array}$ \\
\hline $\begin{array}{l}\text { 产 } \\
\text { 든 }\end{array}$ & $\begin{array}{l}\text { Z zagadnieniami polityki przestrzennej można powiązać } \\
\text { w szczególności cel rewitalizacji związany z rozbudową i modernizacją } \\
\text { infrastruktury służącej rozwojowi oferty kultury, rekreacji i edukacji } \\
\text { Wśród przedsięwzięć rewitalizacyjnych z polityką przestrzenną można } \\
\text { powiązać założenia dotyczące budowy poszczególnych obiektów, } \\
\text { np. centrum kultury, czy szersze zagospodarowanie terenów } \\
\text { turystyczno-rekreacyjnych }\end{array}$ & Brak \\
\hline
\end{tabular}


cd. tabeli 1

\begin{tabular}{|c|c|c|}
\hline Gmina & $\begin{array}{l}\text { Charakterystyka wybranych postanowień gminnych programów } \\
\text { rewitalizacji ujmujących kontekst związany z polityką przestrzenną }\end{array}$ & $\begin{array}{l}\text { Ponadstandardowe postanowienia } \\
\text { uchwał wyznaczających obszar } \\
\text { rewitalizacji, postanowienie uchwał } \\
\text { wyznaczających Specjalne Strefy } \\
\text { Rewitalizacji }\end{array}$ \\
\hline 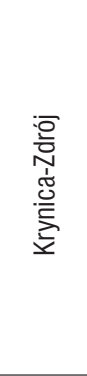 & $\begin{array}{l}\text { Jako przesłankę wyboru obszaru rewitalizacji wskazano brak jasnej } \\
\text { wizji rozwoju obszaru centrum miasta i ustalenia jego jednorodnych } \\
\text { funkcji } \\
\text { Wśród postulowanych działań znajdują się poprawa } \\
\text { zagospodarowania przestrzeni publicznej oraz wzmocnienie funkcji } \\
\text { turystycznej, kulturowej i uzdrowiskowej terenów } \\
\text { Wśród celów rewitalizacji są wyodrębnione takie, jak rozwój } \\
\text { infrastruktury, a także rozwój przestrzenny przy zachowaniu } \\
\text { dziedzictwa kulturalnego i poprawie środowiska, a także odbudowa } \\
\text { zasobu mieszkaniowego i porządkowanie przestrzeni } \\
\text { Jednym z celów jest budowa budynków o funkcji mieszkaniowej }\end{array}$ & $\begin{array}{l}\text { W uchwale wyznaczającej obszar } \\
\text { rewitalizacji ustanowiono prawo } \\
\text { pierwokupu na rzecz gminy } \\
\text { wszystkich nieruchomości } \\
\text { położonych w obszarze rewitalizacji }\end{array}$ \\
\hline № & $\begin{array}{l}\text { Wśród powodów stwierdzenia konieczności rewitalizacji wyróżniono } \\
\text { chaotyczne wymieszanie funkcji, a także niski standard terenów } \\
\text { rekreacyjnych } \\
\text { W wyniku rewitalizacji postuluje się zapobieganie negatywnym } \\
\text { z perspektywy przestrzennej procesom, w szczególności gettoizacji } \\
\text { przy nowym budownictwie mieszkaniowym } \\
\text { Celem jest również kształtowanie kulturowej funkcji centrum miasta } \\
\text { Wśród przedsięwzięć znajdują się postulaty budowy/przebudowy } \\
\text { budynków służących rozwojowi społecznego budownictwa } \\
\text { czynszowego oraz tworzenie przyjaznych przestrzeni miejskich }\end{array}$ & $\begin{array}{l}\text { W uchwale wyznaczającej obszar } \\
\text { rewitalizacji ustanowiono prawo } \\
\text { pierwokupu na rzecz gminy } \\
\text { wszystkich nieruchomości } \\
\text { położonych w obszarze rewitalizacji }\end{array}$ \\
\hline $\begin{array}{l}\text { ò } \\
\text { 兰 } \\
\text { 志 } \\
\text { 竞 }\end{array}$ & $\begin{array}{l}\text { Wśród celów rewitalizacji wyróżniono poprawę funkcjonalności } \\
\text { przestrzeni publicznej oraz poprawę jakości struktury funkcjonalno- } \\
\text {-przestrzennej } \\
\text { Wśród przedsięwzięć można wyróżnić budowę konkretnych obiektów, } \\
\text { np. budynku centrum sportu i rekreacji oraz kompleksu rekreacyjnego } \\
\text { Postuluje się również adaptację przestrzeni publicznej na cele } \\
\text { utworzenia kompleksu rekreacyjno-kulturowego }\end{array}$ & $\begin{array}{l}\text { W uchwale wyznaczającej Specjalną } \\
\text { Strefę Rewitalizacji ustanowiono } \\
\text { prawo pierwokupu gminy względem } \\
\text { wszystkich nieruchomości } \\
\text { położonych w strefie oraz zasady } \\
\text { udzielenia dotacji właścicielom/ } \\
\text { użytkownikom wieczystym }\end{array}$ \\
\hline $\begin{array}{l}\frac{y}{0} \\
\frac{0}{2}\end{array}$ & $\begin{array}{l}\text { Jako jeden z problemów wskazano braki w zakresie uchwalenia } \\
\text { miejscowych planów zagospodarowania przestrzennego } \\
\text { Za problem uznano również niezagospodarowane tereny i obiekty } \\
\text { poprzemysłowe, a także brak atrakcyjnych przestrzeni publicznych } \\
\text { Wskazano, że budownictwo rozwija się w sposób niekontrolowany } \\
\text { na terenach niezurbanizowanych } \\
\text { Narzędziem rewitalizacji w przypadku jednego z obszarów ma być } \\
\text { (obowiązujący) miejscowy plan zagospodarowania przestrzennego } \\
\text { W określeniu celów problematyka powiązana z polityką przestrzenną } \\
\text { występuje jedynie pośrednio, np. w ramach celu zakładającego } \\
\text { poprawę stanu technicznego zabudowy/standardów przestrzeni } \\
\text { i jakości środowiska } \\
\text { Wśród przedsięwzięć rewitalizacyjnych wyróżniono zagospodarowanie } \\
\text { określonych przestrzeni, a także przywrócenie funkcji społeczno- } \\
\text { gospodarczych innych terenów }\end{array}$ & $\begin{array}{l}\text { W uchwale wyznaczającej } \\
\text { Specjalną Strefę Rewitalizacji } \\
\text { ustanowiono zasady udzielenia } \\
\text { dotacji właścicielom/ użytkownikom } \\
\text { wieczystym }\end{array}$ \\
\hline
\end{tabular}

Źródło: opracowanie własne.

Na podstawie informacji z tabeli 1 można uznać, że instytucjonalne podejście do rewitalizacji w badanych gminach jest zróżnicowane. Przekłada się to przede wszystkim na zakres objętościowy gminnych programów rewitalizacji. Determinuje 
on bowiem stopień szczegółowości poruszanych zagadnień. Z uwagi na powyższe zróżnicowanie dyskusyjne byłoby zestawienie przedmiotowych programów w sposób bardziej syntetyczny. Wybrano więc ujęcie opisowe, w ramach którego przedstawiono te postanowienia, które w ramach każdego programu mogą się łączyć bezpośrednio z polityką przestrzenną lub przynajmniej z jej kluczowymi uwarunkowaniami. Z treści tabeli 1 wynika, że w przeważającym zakresie formalnie stwierdza się jednoznacznie zgodność między programami a studiami uwarunkowań i kierunków zagospodarowania przestrzennego. Zagadnienie związków z uchwalonymi miejscowymi planami zagospodarowania przestrzennego zostało szerzej ujęte w programie dla Płocka, gdzie wskazano na konieczność szerszego dostosowania do programu czterech planów miejscowych.

Trzeba tu dodać, że co do zasady ujęcie zagadnień związanych z polityką przestrzenną $\mathrm{w}$ badanych programach jest odmienne od tego $\mathrm{z}$ aktów planistycznych. Można wyodrębnić dwa kluczowe konteksty obejmujące narzędzia rewitalizacji:

- całościowej, ogólnej oceny stanu przestrzeni na danym obszarze (bez odwołania w tym zakresie do aktów planistycznych),

- indywidualnych zadań, które można potraktować jako uzupełnienie i rozszerzenie kompleksowych koncepcji planistycznych.

Wyjątkiem będą tu przypadki, w których to właśnie plan miejscowy (co ciekawe, nie miejscowy plan rewitalizacji) zostaje uznany za kluczowe narzędzie rewitalizacji - jako sposób realizacji celów rewitalizacji. Zróżnicowany jest również zakres powiązania poszczególnych celów rewitalizacji ze sferą przestrzenną. Niniejsze, zauważalne $\mathrm{w}$ tabeli 1 zróżnicowanie również może zostać uznane za przejaw niesprawności władz publicznych. Postulowany bowiem związek gminnego programu rewitalizacji z aktami planistycznymi, chociaż formalnie stwierdzany, w rzeczywistości jest w ograniczonym zakresie wykorzystany. Zdefiniowanie ogólnych problemów przestrzennych w programie nie przekłada się przeważnie na zmiany aktów przestrzennych (można odnieść wrażenie, że nawet takie sformułowania, jak „zagospodarowanie” są odmiennie rozumiane w obu tych sferach).

Osobno należy ocenić „ponadstandardowe” rozwiązania związane z rewitalizacją. Należy do nich zaliczyć szerszy od minimalnego zakres uchwał wyznaczających obszar rewitalizacji, a także ewentualne wyznaczenie specjalnej strefy rewitalizacji (i jej zakres). Z informacji podanych w tabeli 1 wynika, że we wskazanych gminach podejmuje się działania w ograniczonym stopniu. Przede wszystkim sprowadza się to do ustanowienia możliwości skorzystania przez gminy z prawa pierwokupu. Nie obejmuje natomiast bezpośredniej ingerencji w sferę polityki przestrzennej (np. poprzez ograniczenie możliwości wydawania decyzji o warunkach zabudowy). 
Tabela 2. Narzędzia partycypacji związane $z$ rewitalizacją $w$ badanych gminach

\begin{tabular}{|c|c|c|}
\hline $\begin{array}{c}\text { Nazwa } \\
\text { gminy }\end{array}$ & $\begin{array}{l}\text { Narzędzia partycypacji na poziomie GPR } \\
\text { (wybrane elementy), tj. wyznaczenie obszaru } \\
\text { zdegradowanego i rewitalizacji oraz konsultacje } \\
\text { projektu uchwały w sprawie przyjęcia GPR }\end{array}$ & $\begin{array}{l}\text { Konsultacje dotyczące projektu uchwały w sprawie } \\
\text { Komitetu Rewitalizacji } \\
\text { Skład (interesariusze), upublicznienie wyników prac }\end{array}$ \\
\hline 등 & $\begin{array}{l}\text { Wyznaczenie obszaru rewitalizacji: zbieranie } \\
\text { uwag z wykorzystaniem formularza (papierowego } \\
\text { i online), spotkania informacyjne, spacer studyjny } \\
\text { Konsultacje dotyczące Projektu GPR - formy: } \\
\text { zbieranie uwag z wykorzystaniem formularza } \\
\text { (papierowego i online), spotkania konsultacyjne } \\
\text { - zrealizowano trzy } \\
\text { Ocena i aktualizacja GPR (2018 r.) - formy } \\
\text { konsultacji: zbieranie uwag w postaci papierowej, } \\
\text { zbieranie uwag w postaci elektronicznej, } \\
\text { spotkanie konsultacyjne, spacer studyjny } \\
\text { (spotkanie i spacer odbyły się tego samego dnia) } \\
\text { Ankieta nt. ogólnej sytuacji społeczno- } \\
\text { gospodarczej została przeprowadzona } \\
\text { wśród mieszkańców obszaru rewitalizacji } \\
\text { (osobna ankieta była skierowana do osób } \\
\text { niepełnosprawnych), wykonano } 27 \text { ankiet/ } \\
\text { wywiadów pogłębionych }\end{array}$ & $\begin{array}{l}\text { Konsultacje dotyczące projektu uchwały w sprawie } \\
\text { zasad wyznaczania, składu oraz zasad działania Komitetu } \\
\text { Rewitalizacji: uwagi pisemne i e-mailowe, dwa spotkania } \\
\text { konsultacyjne } \\
\text { W skład Komitetu wchodzi od } 6 \text { do } 12 \text { członków, } \\
\text { w tym: przynajmniej jeden przedstawiciel Urzędu Gminy } \\
\text { Gnojnik, wskazany przez Wójta Gminy, przynajmniej } \\
\text { jeden przedstawiciel Rady Gminy Gnojnik, przynajmniej } \\
\text { jeden przedstawiciel przedsiębiorców, przynajmniej } \\
\text { jeden przedstawiciel organizacji pozarządowych, } \\
\text { przynajmniej po jednym przedstawicielu mieszkańców } \\
\text { każdego podobszaru rewitalizacji (przy czym nie } \\
\text { mogą być to osoby zatrudnione w Urzędzie Gminy ani } \\
\text { w podmiotach stanowiących jednostki organizacyjne } \\
\text { Gminy) } \\
\text { Brak dostępnych danych o składzie i działaniach }\end{array}$ \\
\hline 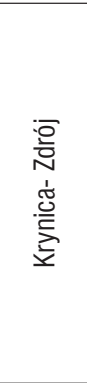 & $\begin{array}{l}\text { Wyznaczenie obszaru rewitalizacji: zbieranie uwag } \\
\text { i opinii w formie papierowej oraz elektronicznej } \\
\text { z wykorzystaniem ustalonego formularza } \\
\text { konsultacyjnego, zbieranie uwag ustnych oraz } \\
\text { spotkanie konsultacyjne } \\
\text { Konsultacje dotyczące Projektu GPR - formy: } \\
\text { zbieranie uwag i opinii w formie papierowej oraz } \\
\text { elektronicznej z wykorzystaniem ustalonego } \\
\text { formularza konsultacyjnego, zbieranie uwag } \\
\text { ustnych oraz spotkania konsultacyjne - odbyły } \\
\text { się trzy w odstępach tygodniowych }\end{array}$ & $\begin{array}{l}\text { Konsultacje dotyczące zasad wyznaczania składu oraz } \\
\text { zasad działania Komitetu Rewitalizacji: uwagi i opinie } \\
\text { w formie papierowej i elektronicznej z wykorzystaniem } \\
\text { formularza, zbieranie uwag ustnych, spotkanie } \\
\text { konsultacyjne } \\
\text { Brak dostępnych online informacji o składzie i wynikach } \\
\text { działania Komitetu }\end{array}$ \\
\hline 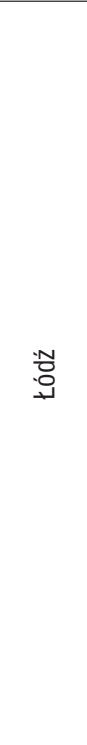 & $\begin{array}{l}\text { Wyznaczenie obszaru rewitalizacji: zbieranie } \\
\text { uwag w postaci papierowej i elektronicznej } \\
\text { z wykorzystaniem formularza konsultacyjnego, } \\
\text { spotkania konsultacyjne } \\
\text { Konsultacje dotyczące Projektu GPR - formy: } \\
\text { zbieranie uwag w postaci papierowej } \\
\text { i elektronicznej z wykorzystaniem formularza } \\
\text { konsultacyjnego, spotkania otwarte i uwagi do } \\
\text { protokołu, aktualizacja GPR - formy: zbieranie } \\
\text { uwag w postaci papierowej i elektronicznej } \\
\text { z wykorzystaniem formularza konsultacyjnego, } \\
\text { cztery spotkania konsultacyjne z różnymi grupami } \\
\text { interesariuszy, dwa warsztaty z różnymi grupami } \\
\text { interesariuszy }\end{array}$ & $\begin{array}{l}\text { Konsultacje dotyczące zasad wyznaczania składu oraz } \\
\text { zasad działania Komitetu Rewitalizacji: zbieranie uwag } \\
\text { w postaci papierowej i elektronicznej oraz w specjalnym } \\
\text { punkcie informacyjnym w Biurze Rewitalizacji UM } \\
\text { Komitet funkcjonuje od } 2017 \text { r. i liczy } 29 \text { członków } \\
\text { (wcześniej nawet 34) w tym: trzech przedstawicieli } \\
\text { organizacji pozarządowych, trzech przedstawicieli } \\
\text { podmiotów prowadzących działalność gospodarczą } \\
\text { na obszarze rewitalizacji, trzech przedstawicieli wspólnot } \\
\text { mieszkaniowych z obszaru rewitalizacji, jeden właściciel } \\
\text { nieruchomości z obszaru rewitalizacji (z wyłączeniem } \\
\text { wspólnot mieszkaniowych), czterech przedstawicieli } \\
\text { mieszkańców w tym trzech z obszaru rewitalizacji; } \\
\text { po jednym przedstawicielu: uczelni wyższych, instytucji } \\
\text { kultury, samorządów gospodarzy, gestorów sieci, } \\
\text { dwóch przedstawicieli szkół i placówek oświatowych } \\
\text { z terenu rewitalizacji, czterech ekspertów specjalistów } \\
\text { ds. poszczególnych celów rewitalizacji oraz pięciu } \\
\text { przedstawicieli miasta Łodzi } \\
\text { Jego działania, łącznie z relacjami z posiedzeń, } \\
\text { są relacjonowane i dostępne online https://rewitalizacja. } \\
\text { uml.lodz.pl/rewitalizacja/komitet-rewitalizacji// }\end{array}$ \\
\hline
\end{tabular}




\begin{tabular}{|c|c|c|}
\hline $\begin{array}{c}\text { Nazwa } \\
\text { gminy }\end{array}$ & $\begin{array}{l}\text { Narzędzia partycypacji na poziomie GPR } \\
\text { (wybrane elementy), tj. wyznaczenie obszaru } \\
\text { zdegradowanego i rewitalizacji oraz konsultacje } \\
\text { projektu uchwały w sprawie przyjęcia GPR }\end{array}$ & $\begin{array}{l}\text { Konsultacje dotyczące projektu uchwały w sprawie } \\
\text { Komitetu Rewitalizacji } \\
\text { Skład (interesariusze), upublicznienie wyników prac }\end{array}$ \\
\hline 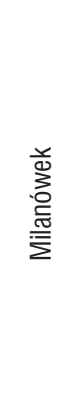 & $\begin{array}{l}\text { Wyznaczenie obszaru rewitalizacji: zbieranie } \\
\text { uwag w formie elektronicznej, zbieranie uwag } \\
\text { ustnych, warsztaty konsultacyjne związane } \\
\text { z wyznaczeniem obszaru zdegradowanego } \\
\text { i rewitalizacji } \\
\text { Konsultacje dotyczące Projektu GPR } \\
\text { - formy: zbieranie uwag w formie papierowej } \\
\text { i elektronicznej, poprzez przesłanie } \\
\text { opinii na wskazany adres e-mail, ankiety } \\
\text { elektronicznej, ustnego zbierania uwag, spotkania } \\
\text { konsultacyjnego (jednego) }\end{array}$ & $\begin{array}{l}\text { Konsultacje dotyczące zasad wyznaczania, składu } \\
\text { oraz zasad działania Komitetu Rewitalizacji: zbieranie } \\
\text { uwag w postaci papierowej lub elektronicznej, ankiety } \\
\text { elektronicznej i papierowej oraz ustnego zbierania uwag } \\
\text { Komitet, zgodnie z zapisami przyjętego regulaminu liczy } \\
\text { sześć osób, w tym: dwóch przedstawicieli Urzędu Miasta } \\
\text { Milanówka, jeden przedstawiciel jednostki organizacyjnej } \\
\text { (Ośrodek Pomocy Społecznej), jeden przedstawiciel Rady } \\
\text { Miasta Milanówka, jeden przedstawiciel Rady Seniorów } \\
\text { Miasta Milanówka oraz jeden przedstawiciel obszaru } \\
\text { rewitalizacji (mieszkaniec) } \\
\text { Brak dostępnych danych o działaniach Komitetu }\end{array}$ \\
\hline$\frac{\text { 늠 }}{\frac{0}{2}}$ & $\begin{array}{l}\text { Wyznaczenie obszarów zdegradowanego } \\
\text { i obszaru rewitalizacji: uwagi w formie ustnej } \\
\text { i pisemnej, spotkania, debata, spacer studyjny, } \\
\text { ankieta } \\
\text { Na etapie projektu GPR zastosowano te same } \\
\text { formy }\end{array}$ & $\begin{array}{l}\text { Konsultacje dotyczące zasad wyznaczania, składu oraz } \\
\text { zasad działania Komitetu Rewitalizacji: zbieranie uwag } \\
\text { w formie papierowej i elektronicznej oraz spotkanie } \\
\text { konsultacyjne i zbieranie uwag ustnych } \\
\text { Komitet powołano w } 2016 \text { r., jego skład był kilkakrotnie } \\
\text { zmieniany. Obecnie (od stycznia } 2020 \text { r.) tworzy go } \\
13 \text { osób, w tym: siedmiu mieszkańców, po jednym } \\
\text { przedstawicielu podmiotów prowadzących działalność } \\
\text { gospodarczą i społeczną na terenie miasta, dwóch } \\
\text { przedstawicieli właścicieli/użytkowników wieczystych } \\
\text { nieruchomości/podmiotów zarządzających } \\
\text { nieruchomościami znajdującymi się na obszarze } \\
\text { rewitalizacji oraz prezes Zarządu Agencji Rewitalizacji } \\
\text { Starówki ARS Sp. z o.o. i dyrektor Wydziału Zdrowia } \\
\text { i Spraw Społecznych } \\
\text { Komitet przedstawił stanowisko do powołania Specjalnej } \\
\text { Strefy Rewitalizacji, brak informacji o innych wynikach } \\
\text { prac Komitetu }\end{array}$ \\
\hline
\end{tabular}

Źródło: opracowanie własne.

W badanych przypadkach narzędzia rewitalizacji nie są więc wykorzystywane w pełnym zakresie (obejmującym wszystkie powiązane z nimi możliwości). Problemem jest również niedoprecyzowane ujęcie terminologiczne zagadnień przestrzennych. W konsekwencji, w przypadku braku bezpośredniego powołania na te narzędzia w gminnym programie rewitalizacji, nie muszą one odgrywać w tym kontekście istotnej roli (albo, w lepszym wariancie, rola ta będzie co najwyżej dorozumiana). Stopień dostosowania i wykorzystania przy okazji rewitalizacji narzędzi polityki przestrzennej bywa więc fakultatywny. Dopuszczając w indywidualnych przypadkach taki stan rzeczy, trzeba jednak zwrócić uwagę na zróżnicowane ujęcia terminologiczne poszczególnych kwestii. W związku z prowadzoną dyskusją o zintegrowanej polityce rozwoju należy wskazać, że taka integracja powinna być ujęta także $\mathrm{w}$ analizowanym kontekście. 
Analizując dane zestawione w tabeli 2 oraz szerzej proces partycypacji jako narzędzie rewitalizacji, należy wskazać kilka prawidłowości:

- gminy stosują narzędzia partycypacji wymienianie w ustawie, wychodząc zazwyczaj poza minimum wynikające z przepisów (co najmniej cztery formy partycypacji, dwie obligatoryjne i dwie ponad to - najczęściej są to: spotkania konsultacyjne, warsztaty, ankiety oraz zbieranie uwag ustnych do protokołu),

- gminy mające inne, ponadstandardowe doświadczenia z włączaniem interesariuszy w swoje działania (np. Łódź, Gnojnik) stosują formy bardziej aktywizujące społeczność lokalną,

- liczba stosowanych narzędzi partycypacji nie przekłada się na zwiększenie liczby partycypujących (wyjątek stanowią jedynie ankiety online, warsztaty i spacery studyjne, w których uczestniczą zazwyczaj pasjonaci-społecznicy - widać to nawet po dokładnych analizach ogłoszeń informacyjnych, na tego typu spotkania przewiduje się często ok. godziny),

- Komitet Rewitalizacji, w założeniu mający możliwie największy wpływ na partycypację w podejmowaniu decyzji, jest ciałem w niektórych gminach nie w pełni obsadzonym (nie dotyczy to tylko małych gmin, nawet w Płocku w poprzednich kadencjach Komitetu był problem $\mathrm{z}$ obsadzeniem miejsc zarezerwowanych dla przedstawiciela organizacji gospodarczych i społecznych działających na terenie rewitalizacji). Najliczniej reprezentowani są interesariusze w Komitecie Rewitalizacji w Łodzi. W Gnojniku i Krynicy niemożliwe okazało się dotarcie do składu Komitetu i wyników jego pracy. Upublicznianie wyników prac praktycznie nie występuje - wyjątkiem jest tu Łódź - co jest o tyle dziwne, że nawet interesariusze wybierający wcześniej swoich przedstawicieli nie mają wglądu do wyników ich prac i do podejmowanych decyzji,

- ogólnie konsultacje społeczne (informacje o nich) są dobrze widoczne na stronach analizowanych gmin - stanowią albo osobną zakładkę (czy kafelek), albo są wyraźnie wyróżnione w części strony dedykowanej mieszkańcom. Nieco inaczej jest $\mathrm{z}$ wynikami konsultacji, te często zamieszczane są w BIP i ich prześledzenie wymaga więcej trudu.

$$
* * *
$$

Wprowadzanie ustawy o rewitalizacji stworzyło gminom możliwości wykorzystania nowych narzędzi, które służą kształtowaniu polityki przestrzennej (przynajmniej teoretycznie), w tym narzędzi związanych ze sferą prawno-przestrzenną i partycypacją. Te pierwsze mogłyby potencjalnie korygować faktyczne stosowanie dotychczasowych podstawowych narzędzi polityki przestrzennej (i tym samym ograniczać niesprawność władz publicznych). 
Z zaprezentowanych wyżej badań wynika, że korekta ta mogłaby mieć konkretną postać i polegać przede wszystkim na tym, że organ gminy doprecyzowuje ramy konkretnych inwestycji oraz wiąże je z procesem rewitalizacji. Badania wskazują, że gminy w mniejszym zakresie dokonują całościowej korekty podstawowych narzędzi polityki przestrzennej i nie zmieniają ich roli odgrywanej w swojej przestrzeni.

Wyrazem tego jest choćby brak miejscowych planów rewitalizacji (obserwowany w skali całego kraju), jak również ograniczona ingerencja innych narzędzi (sprowadzająca się zazwyczaj do stwierdzenia zgodności z nimi konkretnych celów i przedsięwzięć rewitalizacji). Nie przesądzając, że taki silny związek jest każdorazowo bezwzględnie potrzebny, należy wskazać na potrzebę podjęcia szerszych działań w tym zakresie.

Zastosowanie narzędzi partycypacji pozwalałoby ograniczać niesprawność władz publicznych. Mogłoby do tego dojść przede wszystkim w zakresie niewłaściwego lub niepełnego zdiagnozowania problemów stanowiących podstawę dla przeprowadzenia rewitalizacji, w tym niewłaściwego wyodrębnienia dóbr publicznych podlegających ochronie - poprawnie przeprowadzone konsultacje na etapie określania obszaru zdegradowanego i obszaru rewitalizacji pozwalają na eliminowanie tego typu zagrożeń. Jak wskazuje dokonana analiza, na tym etapie stosowane są zróżnicowane formy partycypacji, w tym aktywizujące interesariuszy i dające możliwości współpracy w terenie.

Przeprowadzona analiza potwierdza brak mapowania interesariuszy i posługiwanie się jedynie enumeratywną ich listą wynikającą z zapisów ustawy - także narzędzia partycypacji bywają te same bez względu na etap prowadzonego procesu i zakładaną współpracę z poszczególnymi grupami interesariuszy. W świetle analiz wydaje się, że działanie Komitetów Rewitalizacji mogłoby być lepiej wykorzystywanym narzędziem realizowania GPR przez interesariuszy i ograniczania niesprawności władz publicznych.

\section{Bibliografia}

Arnstein, S.R. (2016). A ladder of citizen participation. Journal of the American Institute of Planners, 35(4): 216.

Badanie efektywności mechanizmów konsultacji społecznych. Raport końcowy - załąznik nr 5(2011). Warszawa: Ministerstwo Pracy i Polityki Społecznej.

Długosz, D., Wygnański, J. (2005). Obywatele współdecydują. Przewodnik po partycypacji społecznej. Warszawa: Stowarzyszenie na rzecz Forum Inicjatyw Pozarządowych.

Dondorewicz, M., Główczyński, M., Wronkowski, A. (2016). Partycypacja społeczna w rewitalizacji - rola stowarzyszeń lokalnych na przykładzie Poznania. Problemy Rozwoju Miast, Kwartalnik Naukowy Rozwoju Miast, 4(13): 43. 
Drzazga, D. (2018). Systemowe uwarunkowania planowania przestrzennego jako instrumentu osiągania sustensywnego rozwoju. Łódź: Wydawnictwo Uniwersytetu Łódzkiego.

Feltynowski, M. (2018). Planowanie przestrzenne gmin wiejskich. Zastosowanie koncepcji polityki opartej na dowodach. Łódź: Wydawnictwo Uniwersytetu Łódzkiego.

Hajduk, S. (2018). E-partycypacja jako nowoczesna forma komunikacji w zarządzeniu przestrzennym miast. Studia i Prace Kolegium Zarządzania i Finansów, 170: 135-150.

Hołuj, D., Legutko-Kobus, P. (2018a). Partycypacja jako element rewitalizacji (przykłady miast z województwa małopolskiego i mazowieckiego). Studia Ekonomiczne. Zeszyty Naukowe Uniwersytetu Ekonomicznego w Katowicach, 365: 93-119.

Hołuj, D., Legutko-Kobus, P. (2018b). A participatory model of creating revitalisation programmes in Poland - challenges and barriers. Mazowsze Studia Regionalne, 26: 39-42.

Kassen, M. (2020). E-participation actors: understanding roles, connections, partnerships. Knowledge Management Research \& Practice, 1(18): 16-17.

Kowalewski, A. (2019). Interes publiczny i przestrzeń - kilka uwag, w: Zarzadzanie rozwojem współczesnych miast, red. J. Danielewicz, D. Sikora-Fernandez. Łódź: Wydawnictwo Uniwersytetu Łódzkiego: 265-267.

Leszkowicz-Baczyński, J., Marcinów, B. (2019). Uwarunkowania miejskiej aktywności obywatelskiej a jej współczesne realia. Przypadek miasta średniej wielkości. Górnośląskie Studia Socjologiczne. Seria Nowa, 10: 18-29.

Litwińska, E. (2011). Rewitalizacja małych miast w Polsce na tle doświadczeń miast amerykańskich i zachodnioeuropejskich, w: Rewitalizacja, gentryfikacja i problemy rozwoju małych miast, red. K. Heffner, T. Marszał. Warszawa: Studia KPZK PAN, t. CXXXVI: 32-34.

Lorens, P. (2017). Kształtowanie programów rewitalizacji miast w kontekście współczesnych przemian społeczno-ekonomicznych, doktrynalnych i prawnych. Biuletyn KPZK PAN, 264: $16-20$.

Markowski, T., Planowanie przestrzenne i instrumenty jego realizacji w świetle teorii ułomnych rynków, w: Zarządzanie rozwojem przestrzennym miast, red. P. Lorens, J. Martyniu-Pęczek. Gdańsk: Wydawnictwo Urbanista: 28.

Mielczarek-Żejmo, A. (2019). Sieci współrządzenia w procesach rewitalizacji. Rocznik Lubuski, 45(2): 107.

Mikuła, Ł. (2019). Zarządzanie rozwojem przestrzennym obszarów metropolitalnych $w$ świetle koncepcji miękkich przestrzeni planowania. Poznań: Wydawnictwo Naukowe Bogucki.

Muszyńska-Jeleszyńska, D. (2015). Znaczenie konsultacji społecznych w procesach rewitalizacji obszarów miejskich. Ruch Prawniczy, Ekonomiczny i Socjologiczny, 1(77): 259.

Nowak, M. (2017). Niesprawność władz publicznych a system gospodarki przestrzennej. Studia KPZK PAN, t. CLXXV. Warszawa: Komitet Przestrzennego Zagospodarowania Kraju PAN.

Nowak, M., Tokarzewska-Żarna, Z. (2016). Ustawa krajobrazowa, rewitalizacyjna i metropolitalna. Komentarz do przepisów o planowaniu i zagospodarowaniu przestrzennym. Warszawa: C.H. Beck.

Nowakowska, A., Legutko-Kobus, P., Walczak, B.M. (2019). Od rehabilitacji do włączenia społecznego - współczesne ujęcie procesów rewitalizacji. Warszawa: PAN. 
Noworól, A., Noworól, K., Hałat, P. (2012). Partycypacja społeczna w zarządzaniu procesami rewitalizacji. Problemy Rozwoju Miast, 1: 26-39.

Olech, A., Kaźmierczak, T. (2011). Modele partycypacji publicznej, w: Partycypacja publiczna. O uczestnictwie obywateli w życiu wspólnoty lokalnej, red. A. Olech. Warszawa: ISP: 102-109.

Ostrom, E. (2012). Instytucje i środowisko. Zarzadzanie Publiczne, 2(20): 95.

Rembarz, G. (2016). Rewitalizacja Berlina i Lipska jako źródło inspiracji dla polskich praktyk rewitalizacji, w: Wybrane zagadnienia rewitalizacji miast w kontekście przemian społeczno-gospodarczych, red. P. Lorens. Biuletyn KPZK PAN, 264: 26-66.

Staszewska, S., Dajek, O. (2018). Program rewitalizacji a zarządzanie przestrzenne i strategiczne. Biuletyn KPZK PAN, 270: 25-31.

Szlachetko, J., Szlachetko, K. (2019). Udziat interesariuszy w kształtowaniu i prowadzeniu polityki rewitalizacyjnej. Gdańsk: Instytut Metropolitalny.

Śleszyński, P. (2013). Propozycja kompleksowej koncepcji wskaźników zagospodarowania i ładu przestrzennego. Biuletyn KPZK, 252: 178-229.

Ustawa z dnia 9 października 2015 roku o rewitalizacji (2015). Dz.U. 2015, poz. 1777.

Zybała, A. (2019). Polityka przestrzenna i jej rezultaty w warunkach rosnącej złożoności jej problemów. Studia z Polityki Publicznej, 2(22): 112.

Zybała, A. (2012). Polityki publiczne. Doświadczenia w tworzeniu i wykonywaniu programów publicznych $w$ Polsce i innych krajach. Warszawa: Krajowa Szkoła Administracji Publicznej. 
Oficyna Wydawnicza SGH - Szkoła Główna Handlowa w Warszawie 02-554 Warszawa, al. Niepodległości 162

www.wydawnictwo.sgh.waw.pl

e-mail: wydawnictwo@sgh.waw.pl

Projekt okładki

Ad Depositum

Skład i łamanie

DM Quadro

Druk i oprawa

QUICK-DRUK s.c.

Zamówienie 98/IX/20 